\title{
Фармакогенетическое тестирование пациента для подбора терапии НПВП
}

\author{
Пономарева Н. Ю., Митьковский С. В., Митьковский В. Г., Ямпольская Е. Н., \\ Лазарев В. В., Кадникова Н. Г., Кочетков А. В. \\ ФГБУЗ Центральная клиническая больница восстановительного лечения ФМБА России, \\ Московская область, Россия
}

\begin{abstract}
Ключевые слова: генотипирование; фармакогенетическое тестирование; НПВП; болезнь Жильбера; персонализация терапии

Для цитирования:

Пономарева Н.Ю., Митьковский С.В., Митьковский В.Г., Ямпольская Е.Н., Лазарев В.В., Кадникова Н.Г., Кочетков А.В. Фармакогенетическое тестирование пациента для подбора терапии НПВП // Фармакогенетика $u$ фармакогеномика. 2020;(2):38-39. (In Russ). DOI: 10.37489/2588-0527-2020-2-38-39
\end{abstract}

Описание пациента. Пациент А., 39 лет, из отделения травматологии и ортопедии с нейрохирургическими койками ФГБУЗ ЦКБВЛ ФМБА России. Боли в шее и спине на протяжении нескольких лет, с сентября 2019 г. - ухудшение, после курса медикаментозного лечения болевой синдром уменьшился незначительно. Хронический эрозивный гастрит на фоне приёма нестероидных противовоспалительных препаратов (НПВП), лекарственная и пищевая аллергия (на но-шпу, новокаин, соки). При ранее проведённом по поводу гипербилирубинемии (случайная лабораторная находка) исследовании гена уридин-дифосфат-глюкуронил-трансферазы UGT1A1 выявлено 6ТА/7ТА гетерозиготное состояние промоторной области - болезнь Жильбера. Обследован по поводу дорсопатии, торакалгии на фоне остеохондроза шейного отдела позвоночника с болевым и мышечно-тоническим синдромом. На МРТ отмечены: картина дегенеративно-дистрофических изменений шейного отдела позвоночника, грыжи дисков C5-C6, с тенденцией к секвестрации грыжи диска, проявления умеренно выраженного спондилоартроза, спондилез. Консультирован нейрохирургом. По поводу грыжи диска с синдромом компрессионно-шейной миелопатии проведена эндоскопическая микродискэктомия, стабилизирующая операция на уровне C4-C6. Рекомендовано длительное лечение НПВП по поводу выраженного болевого синдрома.

Тип вмешательства. Применяемое лечение до персонализации. Приём НПВП без учёта индивидуального ответа на назначенные фармпрепараты проявлялся повторными эпизодами развития нежелательных лекарственных реакций со стороны ЖКТ.

Показания к персонализации. Что послужило поводом применения персонализации? Необходимость дифференцированного подхода для выбора рациональной фармакотерапии на основе генотипирования пациента, снижающей риск нежелательных лекарственных реакций.

Тип персонализации. Какой метод был использован для персонализации терапии? Молекулярно-генетическое исследование (с учётом осложненного семейного анамнеза по СС3, тромбозу, нарушениям углеводного и липидного обмена, онкозаболеваниям) проведено по 254 однонуклеотидным полиморфизмам (single nucleotide polymorphism $\mathrm{SNP}$ ) «Генетический паспорт», включающий, в т. ч. следующие профили лаборатории: детоксикация; метаболизм лекарственных препаратов и алкоголя (13 SNP), риск развития побочных эффектов, определение дозы лекарственных препаратов (9 SNP) и диагностика болезни Жильбера (1 SNP). Биоматериал - венозная кровь с этилендиаминтетрауксусной кислотой (К3-ЭДТА); метод генодиагностики полимеразная цепная реакция (RT-PCR) reverse transcription polymerase chain reaction (выделение, амплификация, наращивание исследуемых таргетных фрагментов генов, детекция полученных результатов; трактовка протоколов генотипирования выявленных полиморфных вариантов генов на основе данных метаанализов по доказанным ассоциациям генотипов с патогенезом заболеваний и особенностями фармакокинетики [1].

Изменения после персонализации. Что предпринято на основе тестирования?

В аналитическом заключении выявлены следующие особенности генотипа (актуальные для пациента в рамках фармакогенетического исследования): гетерозиготный полиморфизм в гене $\boldsymbol{U G T 1 A 1} * 286 T A>7 T A$ rs34815109 6TA/7TA, подтверждающий мягкий ва- 
риант синдрома Жильбера - OMIM\#143500 Gilbert syndrome), который предполагает нарушение метаболизма лекарственных веществ (парацетамол, рифампицин, иринотекан и др.) с дозозависимой гемато- и гепатотоксичностью. При исследовании панели генов, продукты которых ассоциированы с нарушением детоксикации ксенобиотиков, выявлен гетерозиготный полиморфизм генов: CYP2D6 rs1065852; GSTP1 rs1695/rs1138272; NAT2 rs1801280/rs 1799930; TPMT*3C $r s 1142345 / * 3 B \quad r s 1800460 ; \quad C Y P 2 C 19 * 2 \quad r s 4244285$; CYP1A2 rs762551; CYP2C9*2 rs1799853/*3 rs1057910. Для анализа фармакокинетики НПВП пациента актуальны последние 3 гена (подчеркнуты). Из них наиболее важными являются два «медленных варианта»

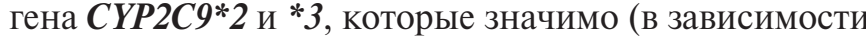
от полиморфизма $-* 2$ или $* 3$ и от гетеро- или гомозиготности) влияют на снижение клиренса различных НПВП - от 0 до $76 \%$. Изоформы СУР2C9*2 и *3 определяют сниженную активность фермента цитохром Р-450, вклад которого в метаболизм различных НПВП составляет от 40 до $90 \%$. Кроме того, необходимо учитывать и другие изоформы Р-450 (СYP2C19; CYP1A2 u $\partial p$.) и ферменты (UGT и $\partial p$.$) , участвуюшие в метабо-$ лизме НПВП [2, 3]. Выявленный генотип, сочетанно предрасполагающий к замедленному метаболизму НПВП, позволяет объяснить развитие нежелательных проявлений эрозивной гастропатии (с высоким риском ульцерации и желудочно-кишечных кровотечений) на фоне приёма таких препаратов, как диклофенак, ибупрофен, пироксикам, которые длительно и в высоких дозах (часто без консультации с врачом) использовались пациентом для купирования болевого синдрома [4]. Баланс эффективности и безопасности лечения болевого синдрома должен тщательно (и в динамике) оцениваться как врачом, который назначает НПВП, так и самим пациентом, который следит за эффективностью принимаемого препарата и проявлениями нежелательных реакций. Необходимо рассмотреть соотношение риск/польза для пациента с учётом: состояния его здоровья (СС3, патология печени, почек и др.) и коморбидности; сочетанного приёма других препаратов (аспирин-содержащих, непрямых антикоагулянтов при СС3), злоупотребления алкоголем. Нежелательные реакции, опосредуемые через ингибиторы ЦОГ-1, приводят к снижению продукции простагландина Е2 и простациклина, к ухудшению почечного кровотока и снижению скорости клубочковой фильтрации. Длительное применение НПВС способствует дегенерации хрящевой ткани суставных поверхностей. Крупномасштабные рандомизированные исследования селективных НПВС зафиксировали кардиоваскулярные осложнения, зависящие напрямую от силы ингибирования ЦОГ-2 (или отношения активности ЦОГ-2/ЦОГ-1), поэтому вальдекоксиб и рофекоксиб были отозваны с рынка, целекоксиб (Целебрекс) и эторикоксиб (Аркоксиа) имеют очень ограниченное применение, а более мягкий ингибитор ЦОГ-2 мелоксикам, не приводит к повышению риска инфаркта миокарда [5].

Выбор наиболее безопасного НПВП на основании результатов генотипирования позволяет исключить препараты, которые более 90 \% метаболизируются выявленными полиморфными вариантами генов и остановиться на других, вклад которых в метаболизм НПВП менее 40-50 \%.

Так, при выявленном генотипе $\boldsymbol{C Y P 2 C}$ * 2 и *3 оптимальным выбором НПВП можно считать неселективный ингибитор Циклооксигеназы ЦОГ1 и ЦОГ2 Напроксен (вклад которого в метаболизм НПВП $<40$ $\%$ и не влияет на клиренс/фармакокинетику) с более низким риском неблагоприятных побочных эффектов как со стороны ЖКТ, так ССЗ и почек.

Динамика. Как изменилось состояние после коррекции терапии на основе персонализации? Рекомендована замена НПВП на менее зависимый от «медленного генотипа» с меньшей силой блокирования ЦОГ неселективный ингибитор напроксен, приём которого был проконтролирован через 3 мес., нежелательных реакций (в т. ч. эрозивного гастрита на ЭГДС) - не выявлено.

Заключение. Вывод по данному случаю, были ли полезны технологии персонализации? Генотипирование, на основе которого строится выбор персонализированной фармакотерапии с наименьшим риском развития нежелательных лекарственных реакций, позволяет избежать ятрогенных осложнений, увеличить эффективность лечения основного заболевания.

\section{Литература / References}

1. Table of Pharmacogenomic Biomarkers in Drug Labels. https://clck. $\mathrm{ru} / \mathrm{Sy} 5 \mathrm{TZ}$

2. Леонова М.В., Алимова Э.Э. Фармакогенетика нестероидных противовоспалительных препаратов: существующие проблемы для клинической практики // Медицинский совет. 2018;21:204-209. [Leonova MV, Alimova EE. Pharmacogenetics of non-steroidal antiinflammatory drugs: existing problems for clinical practice. Meditsinsky Sovet. 2018;21:204-209. (In Russ).] DOI: 10.21518/2079-701X-2018-21204-209.

3. Ашихмин Я.И., Драпкина О.М. Лечение болевого синдрома с позиции эффективности и безопасности // ЭФ. Ревматология. Травматология. Ортопедия. - 2011. - №1. - С. 38-43. [Ashikhmin YaI, Drapkina OM. Lechenie bolevogo sindroma s pozicii effektivnosti i

bezopasnosti. Effective Pharmacotherapy. Rheumatology, Traumatology \& Orthopaedics. 2011;(1):38-43. (In Russ).]

4. Schjerning, AM., McGettigan, P. \& Gislason, G. Cardiovascular effects and safety of (non-aspirin) NSAIDs. Nat Rev Cardiol. 2020;17(9):574-584. DOI: 10.1038/s41569-020-0366-Z

5. Обжерина А.Ю., СычевД.А., Муравьева Ю.В., идр. Полиморфизм СYР2С9: новый фактор риска развития желудочно-кишечных осложнений при применении нестероидных противовоспалительных препаратов // Клиническая фармакология и фармакоэкономика. 2009;2(5):205. [Obzherina AYu, Sychev DA, Muravyeva YuV et al. Polimorfizm CYP2C9: novyj faktor riska razvitiya zheludochno-kishechnyh oslozhnenij pri primenenii nesteroidnyh protivovospalitel'nyh preparatov. Klinicheskaya farmakologiya i farmakoekonomika. 2009;2(5):20-5. (In Russ).] 